\title{
Characterizing the Genetic Diversity of the Clavibacter michiganensis subsp. michiganensis Population in New York
}

\author{
Matthew A. Tancos, Holly W. Lange, and Christine D. Smart
}

Department of Plant Pathology and Plant-Microbe Biology, Cornell University, Geneva, NY. Accepted for publication 2 September 2014.

\begin{abstract}
Tancos, M. A., Lange, H. W., and Smart, C. D. 2015. Characterizing the genetic diversity of the Clavibacter michiganensis subsp. michiganensis population in New York. Phytopathology 105:169-179.

New York Clavibacter michiganensis subsp. michiganensis isolates, collected from disparate bacterial canker of tomato outbreaks over the past 11 years, were characterized with a multilocus sequence analysis (MLSA) scheme that differentiated the 51 isolates into 21 haplotypes with a discriminatory power of 0.944 . The MLSA scheme consisted of five housekeeping genes $(k d p A, s d h A, \operatorname{dnaA}$, ligA, and $g y r B)$ and three putative pathogenicity genes (celA, tomA, and nagA). Repetitive polymerase chain reaction (PCR), with the BOX-A1R primer, confirmed the

York by demonstrating that all six PCR patterns (A, B, 13C, 65C, 81C, and D) were present, with PCR patterns $\mathrm{C}$ and $\mathrm{A}$ being the most common. The MLSA scheme provided higher resolving power than the current repetitive-PCR approach. The plasmid profiles of New York isolates were diverse and differed from reference strain NCPPB382. PCR analysis indicated that the presence of putative pathogenicity genes varied between isolates and highlighted the ephemeral nature of pathogenicity genes in field populations of C. michiganensis subsp. michiganensis. Analysis of molecular variance between Serbian and New York C. michiganensis subsp. michiganensis isolates demonstrated that the two populations were not significantly different, with $98 \%$ genetic variation within each population and only $2 \%$ genetic variation between populations.
\end{abstract} high diversity of $C$. michiganensis subsp. michiganensis isolates in New
Clavibacter michiganensis subsp. michiganensis, the causal agent of bacterial canker of tomato (Solanum lycopersicum), is a quarantined phytopathogen in Europe, Asia, Africa, and the Caribbean (23). This gram-positive bacterium is present in many tomato-producing regions, and can rapidly spread globally through contaminated seed $(23,43)$. C. michiganensis subsp. michiganensis spreads systemically throughout the host's vascular system via the xylem, and radiates outward into the surrounding tissue when high titers are reached $(9,43)$. Once introduced, C. michiganensis subsp. michiganensis spreads epiphytically by splashing water or mechanically via workers or equipment $(5,7)$. Bacterial canker of tomato can be difficult to control due to the lack of resistant cultivars, ineffective chemical controls, and poor sanitation practices $(38,45)$.

Based upon the genome sequence of reference strain NCPPB382, C. michiganensis subsp. michiganensis possesses an arsenal of secreted serine proteases and cell-wall-degrading enzymes, which are located within a chromosomal pathogenicity island (PAI) and two plasmids (pCM1 and pCM2) $(1,12,13)$. The PAI is approximately $129 \mathrm{~kb}$ with a low GC content (64 to 66\%), relative to the genome $(72.7 \%)$, and is subdivided into two regions termed the chp and tomA subregions $(13,26,40)$. The conjugative plasmids pCM1 $(27 \mathrm{~kb})$ and pCM2 $(70 \mathrm{~kb})$ can be transferred throughout a population (8). The current functions or targets of proteins produced by many of the putative pathogenicity genes remain undefined; however, they are hypothesized to function in colonization, nutrient acquisition, or host-defense suppression $(8,12,40)$.

The majority of $C$. michiganensis subsp. michiganensis studies have predominately focused on the pathogenic nature of the

Corresponding author: C. D. Smart; E-mail address: cds14@cornell.edu

http://dx.doi.org/10.1094/PHYTO-06-14-0178-R

(c) 2015 The American Phytopathological Society sequenced strain NCPPB382 $(9,13,26)$; however, studies have recently begun to look at the diversity of field isolates, with differences such as plasmid number and presence or absence of putative pathogenicity genes being readily observed with highly virulent field isolates $(14,18,28,29,33,47)$. Due to a deeper understanding of field diversity, diagnostic approaches have been tailored to reduce false negatives by detecting diverse virulent and avirulent $C$. michiganensis subsp. michiganensis isolates collected from seed and tissue (47).

DNA fingerprinting techniques such as repetitive sequencebased polymerase chain reaction (rep-PCR) have been the predominant method used to characterize and investigate the epidemiology of $C$. michiganensis subsp. michiganensis populations internationally $(17,18,22,24,29,33)$. Within rep-PCR, the BOX-A1R primer is commonly able to differentiate C. michiganensis subsp. michiganensis isolates into four main PCR patterns (A, B, C, and D), and the C PCR pattern can be further segregated into three subgroups (13C, 65C, and 81C) (24). However, the limited differentiation of isolates, incorrect identification of PCR patterns based on the subjectiveness of gels, and difficultly in interlab reproducibility reduces the overall effectiveness of this technique. Conversely, sequencing approaches such as multilocus sequence analysis (MLSA), multilocus sequence typing (MLST), and simple-sequence repeats have provided a quick, efficient, and reproducible approach to microbial characterization, with whole-genome sequencing quickly becoming the gold standard $(20,28,48)$.

Within New York, annual bacterial canker outbreaks occur throughout greenhouse and field environments; however, the diversity of $C$. michiganensis subsp. michiganensis isolates remains unexplored. The objectives of this study were to screen New York $C$. michiganensis subsp. michiganensis field isolates, which were collected over an 11-year period, with an MLSA scheme and (i) identify the diversity among isolates and (ii) compare the New York isolates with other $C$. michiganensis subsp. michiganensis populations. 


\section{MATERIALS AND METHODS}

Bacterial isolates and growth conditions. The $C$. michiganensis subsp. michiganensis isolates utilized in the present study, except for 10-4R, were isolated from diseased tissue collected in New York during multiple bacterial canker outbreaks using D2ANX semiselective media (Table 1; Fig. 1) (11). Isolate 10-4R was isolated from irrigation water in eastern New York (16). All C. michiganensis subsp. michiganensis isolates were stored in $35 \%$ glycerol at $-80^{\circ} \mathrm{C}$.

Pathogenicity assays. Tomato (S. lycopersicum) 'Mountain Fresh Plus' seedlings were grown in a Cornell potting mix (composed of peat, perlite, and vermiculite in a 4:1:1 ratio) with a photoperiod of $14 \mathrm{~h}$ of light and $10 \mathrm{~h}$ of darkness in the greenhouse. C. michiganensis subsp. michiganensis field isolates were grown for $72 \mathrm{~h}$ on D2ANX agar plates and inoculated into approximately 3 week-old tomato seedlings ( $n=3$ per isolate) by pricking the stem between the cotyledons with a sterile needle dipped in an individual C. michiganensis subsp. michiganensis colony, or sterile water as a negative control (36). After the first week, tomato plants were screened daily for characteristic wilting and chlorosis associated with bacterial canker, as previously described (1). Observations continued until all plants died or until 28 days postinoculation (dpi). Three tomato plants composed a replicate, and the entire experiment was repeated for a total of six plants per isolate.

Plasmid profiles. To assay New York isolates for the presence of plasmids ( $n=36$, plus NCPPB382 and CMM100), an individual $C$. michiganensis subsp. michiganensis $\mathrm{CFU}$ was grown at $27^{\circ} \mathrm{C}$ with shaking at $140 \mathrm{rpm}$ for $36 \mathrm{~h}$ in $30 \mathrm{ml}$ of liquid LuriaBertani (LB), before being transferred to $500 \mathrm{ml}$ of liquid LB for an additional $24 \mathrm{~h}$. Plasmid DNA was isolated with a Qiagen Large-construct kit (Qiagen, Enlo, The Netherlands) according to the manufacturer's instructions, except that lysozyme at $5 \mathrm{mg} / \mathrm{ml}$ was added to the resuspension buffer (reagent P1). All DNA was quantified with a Nanodrop ND-1000 (Wilmington, DE). Plasmid

TABLE 1. Clavibacter michiganensis subsp. michiganensis isolates used in this study

\begin{tabular}{|c|c|c|c|c|c|}
\hline Isolate & New York county of origin & County symbol & Year collected & BOX-A1R pattern & Reference \\
\hline 0572 & Ulster & ULT & 2005 & $13 \mathrm{C}$ & This study \\
\hline 0582 & Albany & ALB & 2005 & $13 \mathrm{C}$ & This study \\
\hline 0651 & Ulster & ULT & 2006 & $13 \mathrm{C}$ & This study \\
\hline 0654 & Ulster & ULT & 2006 & $13 \mathrm{C}$ & This study \\
\hline 0676 & Orange & ORG & 2006 & $13 \mathrm{C}$ & This study \\
\hline 0690 & Rensselaer & REN & 2006 & $13 \mathrm{C}$ & 43 \\
\hline 13109 & Suffolk & SUF & 2013 & $13 \mathrm{C}$ & This study \\
\hline 13115 & Suffolk & SUF & 2013 & $13 \mathrm{C}$ & This study \\
\hline NCPPB382 & United Kingdom & UK & 1956 & $13 \mathrm{C}$ & NCPPB \\
\hline CMM100 & United Kingdom & UK & 1956 & $13 \mathrm{C}$ & 27 \\
\hline 04100 & Schoharie & $\mathrm{SCH}$ & 2004 & $65 \mathrm{C}$ & This study \\
\hline 04101 & Schoharie & $\mathrm{SCH}$ & 2004 & $65 \mathrm{C}$ & 2 \\
\hline 0748 & Oneida & ONE & 2007 & $65 \mathrm{C}$ & This study \\
\hline 0779 & Oneida & ONE & 2007 & $65 \mathrm{C}$ & This study \\
\hline 0780 & Oneida & ONE & 2007 & $65 \mathrm{C}$ & This study \\
\hline 0784 & Rensselaer & REN & 2007 & $65 \mathrm{C}$ & This study \\
\hline 0785 & Albany & ALB & 2007 & $65 \mathrm{C}$ & This study \\
\hline 09085 & Niagara & NIG & 2009 & $65 \mathrm{C}$ & This study \\
\hline 09086 & Niagara & NIG & 2009 & $65 \mathrm{C}$ & This study \\
\hline $10-4 R$ & Rensselaer & REN & 2010 & $65 \mathrm{C}$ & 16 \\
\hline 11015 & Albany & ALB & 2011 & $65 \mathrm{C}$ & 43 \\
\hline 12069 & Clinton & CLT & 2012 & $65 \mathrm{C}$ & This study \\
\hline 12084 & Rensselaer & REN & 2012 & $65 \mathrm{C}$ & This study \\
\hline 13054 & Genesee & GEN & 2013 & $65 \mathrm{C}$ & This study \\
\hline 13084 & Wayne & WNY & 2013 & $65 \mathrm{C}$ & This study \\
\hline 13091 & Onondaga & OND & 2013 & $65 \mathrm{C}$ & This study \\
\hline 0310 & Washington & WAS & 2003 & $81 C$ & This study \\
\hline 0426 & Washington & WAS & 2004 & $81 \mathrm{C}$ & This study \\
\hline 0580 & Washington & WAS & 2005 & $81 \mathrm{C}$ & This study \\
\hline 0687 & Washington & WAS & 2006 & $81 \mathrm{C}$ & This study \\
\hline 0691 & Washington & WAS & 2006 & $81 C$ & This study \\
\hline 0692 & Washington & WAS & 2006 & $81 \mathrm{C}$ & This study \\
\hline 0763 & Orange & ORG & 2007 & $81 C$ & This study \\
\hline 0767 & Oneida & ONE & 2007 & $81 C$ & 43 \\
\hline 0775 & Oneida & ONE & 2007 & $81 C$ & This study \\
\hline 08223 & Ulster & ULT & 2008 & $81 \mathrm{C}$ & This study \\
\hline 08224 & Ulster & ULT & 2008 & $81 \mathrm{C}$ & This study \\
\hline 09081 & Niagara & NIG & 2009 & $81 C$ & This study \\
\hline 13129 & Suffolk & SUF & 2013 & $81 \mathrm{C}$ & This study \\
\hline 0312 & Erie & ERI & 2003 & A & This study \\
\hline 0314 & Erie & ERI & 2003 & A & This study \\
\hline 0315 & Erie & ERI & 2003 & A & This study \\
\hline 0317 & Ontario & ONT & 2003 & A & This study \\
\hline 0459 & Erie & ERI & 2004 & A & This study \\
\hline 04108 & Albany & ALB & 2004 & A & This study \\
\hline 06124 & Albany & ALB & 2006 & A & This study \\
\hline 12083 & Columbia & $\mathrm{COL}$ & 2012 & A & This study \\
\hline 13048 & Yates & YAT & 2013 & A & This study \\
\hline 13117 & Ontario & ONT & 2013 & A & This study \\
\hline 0581 & Albany & ALB & 2005 & $\mathrm{~B}$ & This study \\
\hline 04106 & Schoharie & $\mathrm{SCH}$ & 2004 & $\mathrm{D}$ & This study \\
\hline 13090 & Cayuga & CAY & 2013 & $\mathrm{D}$ & This study \\
\hline 13134 & Washington & WAS & 2013 & $\mathrm{D}$ & This study \\
\hline
\end{tabular}


diversity was characterized using CHEF-DR II Pulsed-Field Electrophoresis System (Bio-Rad Laboratories, Inc., Hercules, CA) using $6 \mathrm{~V} / \mathrm{cm}, 1 \%$ molecular biology-grade agarose, $0.5 \times$ Tris-borate-EDTA, and a 0.5 - to 10 -s linear ramp factor for a run time of $16 \mathrm{~h}$ at $14^{\circ} \mathrm{C}$. Plasmid DNA was used at $200 \mathrm{ng}$ per well and visualized with ethidium bromide.

Genomic fingerprinting using BOX-A1R rep-PCR. Genomic DNA was extracted with the MasterPure Gram-Positive DNA purification kit (Epicentre, Madison, WI) according to the manufacturer's instructions. All DNA was quantified with a Nanodrop ND-1000. A fingerprint was generated for each isolate collected using the BOX-A1R primer following a previously described protocol $(24,25)$, with a PTC-100 Peltier thermal cycler (MJ Research, Waltham, MA). Reference $C$. michiganensis subsp. michiganensis strains for the six BOX-A1R patterns (A, B, 13C, 65C, $81 \mathrm{C}$, and D) were included with the New York isolates. Extracted total DNA was used at $20 \mathrm{ng}$ per reaction. PCR was performed in $25-\mu$ reactions with the following parameters: initial preheat for $2 \mathrm{~min}$ at $95^{\circ} \mathrm{C} ; 35$ cycles at $94^{\circ} \mathrm{C}$ for $1 \mathrm{~min}, 53^{\circ} \mathrm{C}$ for $1 \mathrm{~min}$, and $65^{\circ} \mathrm{C}$ for $8 \mathrm{~min}$; a final extension at $65^{\circ} \mathrm{C}$ for $15 \mathrm{~min}$; and held at $10^{\circ} \mathrm{C}(25)$. The PCR products $(8 \mu \mathrm{l})$ were run in a $1.5 \%$ agarose gel using $0.5 \times$ Tris-acetate-EDTA buffer at $67 \mathrm{~V}$ for $18 \mathrm{~h}$ at $4^{\circ} \mathrm{C}$.

MLSA of $C$. michiganensis subsp. michiganensis. Primers for the putative pathogenicity genes-celA, nagA, chpE, pat-1, and
phpA-were designed using Primer3 v. $4.0 .0(19,44)$ and the sequenced $C$. michiganensis subsp. michiganensis NCPPB382 genome (Table 2). Primers targeting the housekeeping genes$k d p A$, sdhA, dnaA, ligA, and $g y r B$ - and one additional putative pathogenicity gene (tom $A$ ) had been previously described (28, $35,48)$. In order to enhance the discriminatory power of the initial MLST scheme published by Milijašević-Marčić et al. (2012), additional genes were sequenced, including putative pathogenicity genes (48). Multivirulence-locus sequencing typing, including virulence genes, has been commonly employed to subtype human bacterial pathogens due to the hypervariable nature of virulence genes, thereby increasing the resolving power of sequence analyses $(10,34,39,49)$.

The 11 housekeeping and putative pathogenicity genes were analyzed for each isolate using total DNA (as described above) and gene-specific PCR (Table 2). Amplification was performed in a C1000 Touch Thermal Cycler (Bio-Rad Laboratories, Inc.) using EmeraldAmp GT PCR Master Mix (Takara Bio Inc., Otsu, Shiga, Japan). Extracted total DNA was used at approximately $30 \mathrm{ng}$ per reaction with $10 \mu \mathrm{M}$ each of forward and reverse primers (Table 2). PCR was performed in 25 - $\mu$ l reactions with the following parameters: initial preheat for $3 \mathrm{~min}$ at $95^{\circ} \mathrm{C} ; 35$ cycles at $95^{\circ} \mathrm{C}$ for $30 \mathrm{~s}$, a primer-pair-specific temperature for $30 \mathrm{~s}$ (Table 2), and $72^{\circ} \mathrm{C}$ for $1 \mathrm{~min}$; a final extension at $72^{\circ} \mathrm{C}$ for $5 \mathrm{~min}$; and held at $12^{\circ} \mathrm{C}$. PCR products were electrophoresed on $1 \%$ gels

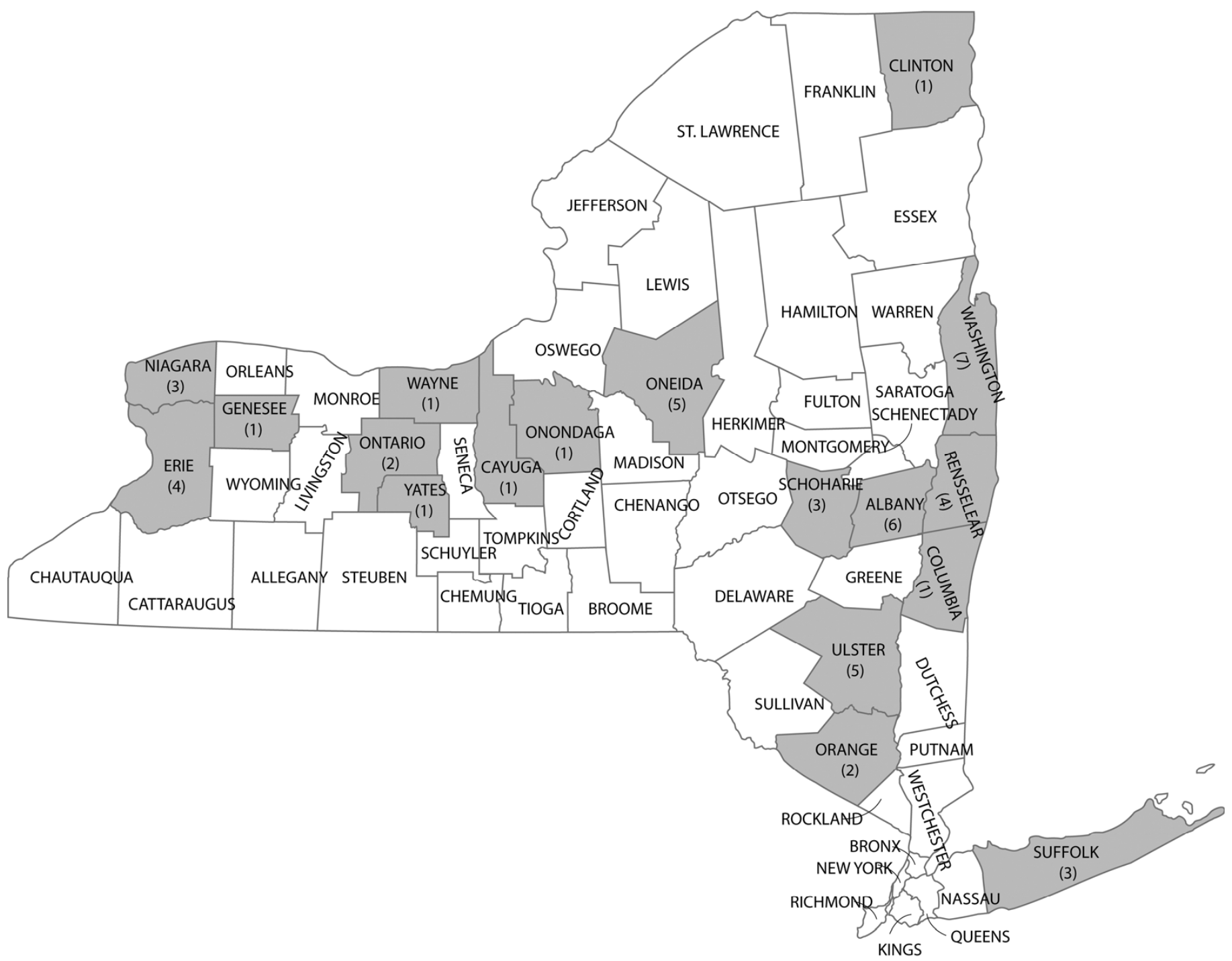

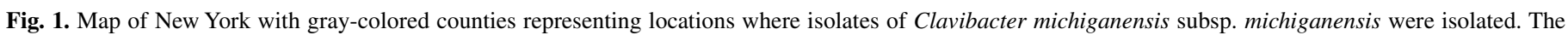
number of isolates collected from each county is provided in parentheses $(n=51)$. 
at $90 \mathrm{~V}$ for $45 \mathrm{~min}$, followed by staining with ethidium bromide. All negative PCR reactions were repeated at least twice.

PCR products were purified with a DNA Clean and Concentrator 25 kit (Zymo Research Inc., Irvine, CA), according to the manufacturer's instructions. The cleaned PCR amplicons were sequenced in both directions on a 3730XL (Sanger) DNA Analyzer (Applied Biosystems) at the Cornell University Life Sciences Core Laboratories Center with the aforementioned primer sets. Our final MLSA scheme consisted of eight genes, consisting of five housekeeping genes $(k d p A, s d h A, \operatorname{dnaA}$, ligA, and $g y r B)$ and three putative pathogenicity genes (celA, tomA, nagA) (Table 2).

Sequence analysis. Raw sequences for each of the eight genes in the MLSA scheme for all 52 isolates were viewed with FinchTV (Geospiza, Inc., Seattle) and manually edited according to peak quality. The sequences were then aligned with Muscle in MEGA 5.2 (42) on an individual gene basis or concatenated. Genes that were missing in a given isolate were treated as deletions in further analyses (46). Consensus sequences were used to generate maximum-likelihood (ML) trees based on the TamuraNei model (41) of MEGA 5.2 using all sites, with bootstrapping repetitions of 1,000. Sequences from reference strain C. michiganensis subsp. sepedonicus NCPPB2137 were used as an outgroup (4). Haplotypes were considered unique if the sequence differed by a single nucleotide.

Discriminatory power was calculated using a web-based discriminatory power calculator (http://insilico.ehu.es/mini_tools/ discriminatory_power/index.php). The population genetic structure of the Serbian and New York C. michiganensis subsp. michiganensis isolates were tested using analysis of molecular variance (AMOVA) $(P<0.05)$ via GenAlEx 6.501 with 999 permutations $(30,31)$. The concatenated sequences-ligA, $k d p A, s d h A$, and tomA-from seven Serbian C. michiganensis subsp. michiganensis isolates, representing each of the seven MLST groups, were compared with the same concatenated sequences from each of the 16 housekeeping gene haplotypes observed with the New York $C$. michiganensis subsp. michiganensis isolates (28). Only these four genes could be compared because they were used in both studies.

\section{RESULTS}

Pathogenicity of New York C. michiganensis subsp. michiganensis isolates. In total, 51 C. michiganensis subsp. michiganensis isolates were collected over 11 years (Table 1). Disease incidence in greenhouse-inoculated plants was consistent, except for six isolates that were only capable of producing disease symptoms in $\leq$ four of the six tomato seedlings tested (Table 3 ). New York isolate 09085 resulted in weak disease symptoms in only one of six seedlings, while other isolates started showing symptoms as early as $7 \mathrm{dpi}$. No wilting was observed on any of the six 09085-inoculated tomato seedlings but some chlorosis was observed on one plant during the observation period ( $28 \mathrm{dpi})$. No wilting or chlorosis was observed with any of the plants inoculated with water (negative controls).

Characterization of plasmid profiles. Plasmid diversity was analyzed for a subset of the New York $C$. michiganensis subsp. michiganensis isolates $(n=36)$, representing at least one from each BOX-A1R pattern (Table 3). NCPPB382 and CMM100 were used as positive and negative controls, respectively. In total, 16 unique plasmid patterns-P1 $(n=5), \mathrm{P} 2(n=6), \mathrm{P} 3(n=2), \mathrm{P} 4$ $(n=3), \mathrm{P} 5(n=6), \mathrm{P} 6(n=2), \mathrm{P} 7(n=1), \mathrm{P} 8(n=3), \mathrm{P} 9(n=1)$, $\mathrm{P} 10(n=1), \mathrm{P} 11(n=1), \mathrm{P} 12(n=1), \mathrm{P} 13(n=1), \mathrm{P} 14(n=1)$, $\mathrm{P} 15(n=2)$, and P16 $(n=2)$-were observed in the New York population of $C$. michiganensis subsp. michiganensis (Table 3; Fig. 2). The majority of New York $C$. michiganensis subsp. michiganensis isolate plasmid profiles were different from reference strain NCPPB382 (plasmid pattern P1).

BOX-A1R fingerprints. All six BOX-A1R patterns-A $(n=$ $10), \mathrm{B}(n=1), 13 \mathrm{C}(n=8), 65 \mathrm{C}(n=16), 81 \mathrm{C}(n=13)$, and $\mathrm{D}$ $(n=3)$-were observed in the New York population of C. michiganensis subsp. michiganensis within the past 11 years (Tables 1 and 3). The $\mathrm{C}$ patterns were the most prominent groups observed, with at least one $C$ pattern isolated every year. However, both the $\mathrm{B}$ and D patterns were rare, with only one isolate collected in 2005 and three collected from 2004 to 2013, respectively (Table 1). Differentiation based on the six BOX-A1R patterns resulted in a discriminatory power of 0.785 .

MLSA analyses for $C$. michiganensis subsp. michiganensis. The initial MLSA scheme was to consist of five housekeeping genes $(k d p A, s d h A, d n a A$, $\operatorname{lig} A$, and $g y r B)$ and six putative pathogenicity genes (pat-1, celA, phpA, chpE, tomA, and nagA) (Table 4); however, no polymorphic sites were observed in the pat-1, phpA, or chpE genes when screened with diverse $C$. michiganensis subsp. michiganensis isolates (based on BOX-A1R analysis). The three genes with no polymorphic sites were not included in further phylogenetic analyses but continued to be screened with PCR in order to determine presence or absence in

TABLE 2. Primers used for multilocus sequence analysis

\begin{tabular}{|c|c|c|c|c|c|c|c|}
\hline Gene & Sequence $\left(5^{\prime}-3^{\prime}\right)$ & Gene product & Locus tag & $\begin{array}{l}\mathrm{Tm} \\
\left({ }^{\circ} \mathrm{C}\right)\end{array}$ & $\begin{array}{l}\text { Amplicon size } \\
\text { (bp) }\end{array}$ & $\begin{array}{c}\text { Aligned } \\
\text { fragment (bp) }\end{array}$ & Reference \\
\hline \multirow[t]{2}{*}{$K d p A$} & F:GTGCAGAACTTCGTCTCGG & $\ldots$ & & & & & $\ldots$ \\
\hline & R:GAGCATCATGTTGATCATCG & K+-dependent ATPase & CMM_2751 & 60 & 693 & 670 & 28 \\
\hline \multirow[t]{2}{*}{$\operatorname{Sdh} A$} & F:CCTGGATGTTCGTGTACC & $\ldots$ & & $\ldots$ & $\ldots$ & $\ldots$ & $\ldots$ \\
\hline & R:GAGGACATGGAGTTCTTCC & Succinate dehydrogenase & CMM_0970 & 58 & 778 & 749 & 28 \\
\hline \multirow[t]{2}{*}{ DnaA } & F:TACGGCTTCGACACCTTCG & $\ldots$ & & $\cdots$ & $\ldots$ & $\ldots$ & $\ldots$ \\
\hline & R:CGGTGATCTTCTTGTTGGCG & Replication initiation factor & CMM_0001 & 60 & 933 & 833 & 37,48 \\
\hline \multirow[t]{2}{*}{$\operatorname{Lig} A$} & F:GTTCGACGAGCTGAATGC & $\ldots$ & & $\ldots$ & $\ldots$ & $\ldots$ & $\ldots$ \\
\hline & R:CTCGACCTTCTCCATGAC & DNA ligase & CMM_1404 & 56 & 544 & 524 & 28 \\
\hline \multirow[t]{2}{*}{ GyrB } & F:ACCGTCGAGTTCGACTACGA & $\ldots$ & & $\ldots$ & $\ldots$ & $\ldots$ & $\ldots$ \\
\hline & R:CCTCGGTGTTGCCSARCTT & DNA gyrase, subunit B & CMM_0006 & 60 & 525 & 501 & 35,48 \\
\hline \multirow[t]{2}{*}{ CelA } & F:GTAGGGCACGCATTTCAGAG & $\ldots$ & & $\ldots$ & $\ldots$ & $\ldots$ & $\ldots$ \\
\hline & R:CAATGTCCTTCTTCGCCAGG & Cellulase & pCM1_0020 & 58 & 1,240 & 1,126 & This study \\
\hline \multirow[t]{2}{*}{ TomA } & F:CGAACTCGACCAGGTTCTCG & $\ldots$ & & & $\ldots$ & $\ldots$ & $\ldots$ \\
\hline & R:GGTCTCACGATCGGATCC & Tomatinase & CMM_0090 & 60 & 529 & 509 & 18 \\
\hline \multirow[t]{2}{*}{$\operatorname{NagA}$} & F:AGAACCTGACAACGGTAGCT & $\ldots$ & & .. & $\ldots$ & $\ldots$ & $\ldots$ \\
\hline & R:GCTTCGGTTGTTTACGGGAA & $\beta$-N-acetylglucosaminidase & CMM_0049 & 60 & 796 & 769 & This study \\
\hline \multirow[t]{2}{*}{ ChpE } & F:CCTGACGCTTCTACTTCCGA & $\ldots$ & & $\ldots$ & $\ldots$ & $\ldots$ & $\ldots$ \\
\hline & R:ACGTTTGTGCTGGTCCATTC & Serine protease & CMM_0039 & 58 & 695 & 674 & This study \\
\hline \multirow[t]{2}{*}{ Pat-1 } & F:TGTAGACCGTATAGCCCGTG & $\ldots$ & & $\ldots$ & $\ldots$ & $\ldots$ & $\ldots$ \\
\hline & R:CCTGAGACCTATTACCGCCC & Serine protease & pCM2_0054 & 55 & 850 & 791 & This study \\
\hline \multirow[t]{2}{*}{ PhpA } & F:TCTCGCGAATCAGCCCATAT & $\ldots$ & & $\ldots$ & $\ldots$ & $\ldots$ & $\ldots$ \\
\hline & R:CTCCTCTAGTCTTCACGCCC & Serine protease & pCM2_0053 & 58 & 709 & 688 & This study \\
\hline
\end{tabular}


each C. michiganensis subsp. michiganensis isolate (Table 3). The final MLSA scheme consisted of eight genes consisting of five housekeeping genes $(k d p A, s d h A, \operatorname{dnaA}$, ligA, and $g y r B)$ and three putative pathogenicity genes (celA, tomA, and nagA) (Table 2).
The MLSA scheme could resolve the 51 New York $C$. michiganensis subsp. michiganensis isolates into 21 haplotypes with a discriminatory power of 0.944 , when the five housekeeping genes and three putative pathogenicity genes were concatenated (Table

TABLE 3. Genetic diversity observed among New York Clavibacter michiganensis subsp. michiganensis isolates ${ }^{\mathrm{a}}$

\begin{tabular}{|c|c|c|c|c|c|c|c|c|c|c|c|c|c|c|}
\hline \multirow[b]{2}{*}{ Pattern, isolate ${ }^{b}$} & \multicolumn{3}{|c|}{ Plasmid } & \multicolumn{5}{|c|}{ Chromosome } & \multicolumn{3}{|c|}{$\mathrm{PAI}^{\mathrm{c}}$} & \multirow[b]{2}{*}{ Profile $^{\mathrm{d}}$} & \multirow[b]{2}{*}{$\mathrm{DI}^{\mathrm{e}}$} & \multirow[b]{2}{*}{$\mathrm{Hap}^{\mathrm{f}}$} \\
\hline & pat-1 & celA & phpA & $\operatorname{dnaA}$ & $\operatorname{sdh} A$ & gyrB & $\operatorname{lig} A$ & $k d p A$ & $\operatorname{chpE}$ & tomA & $\operatorname{nag} A$ & & & \\
\hline \multicolumn{15}{|l|}{$13 \mathrm{C}$} \\
\hline NCPPB382 & + & + & + & + & + & + & + & + & + & + & + & $\mathrm{P} 1$ & $5 / 6$ & H1 \\
\hline 0572 & + & + & + & + & + & + & + & + & + & + & + & P11 & $6 / 6$ & H13 \\
\hline 0582 & + & + & + & + & + & + & + & + & + & + & + & $*$ & $6 / 6$ & H14 \\
\hline 0676 & + & + & + & + & + & + & + & + & + & + & + & P15 & $6 / 6$ & H15 \\
\hline 0651 & + & + & + & + & + & + & + & + & + & + & + & P16 & $6 / 6$ & H15 \\
\hline 0654 & + & + & + & + & + & + & + & + & + & + & + & P16 & $6 / 6$ & H15 \\
\hline 13115 & + & + & + & + & + & + & + & + & + & + & + & $*$ & $6 / 6$ & H16 \\
\hline 13109 & + & + & + & + & + & + & + & + & + & + & + & $*$ & $6 / 6$ & H16 \\
\hline 0690 & + & + & + & + & + & + & + & + & + & + & + & $\mathrm{P} 1$ & $5 / 6$ & $\mathrm{H} 21$ \\
\hline CMM100 & - & - & - & + & + & + & + & + & + & + & + & P8 & $2 / 6$ & $* *$ \\
\hline \multicolumn{15}{|l|}{$65 \mathrm{C}$} \\
\hline 09086 & + & + & - & + & + & + & + & + & + & + & + & $\mathrm{P} 2$ & $6 / 6$ & $\mathrm{H} 2$ \\
\hline 0785 & + & + & + & + & + & + & + & + & + & + & + & $\mathrm{P} 1$ & $6 / 6$ & H5 \\
\hline 11015 & + & + & + & + & + & + & + & + & + & + & + & $\mathrm{P} 1$ & $6 / 6$ & H5 \\
\hline 12069 & + & + & + & + & + & + & + & + & + & + & + & P6 & $6 / 6$ & H6 \\
\hline 13091 & - & + & - & + & + & + & + & + & + & + & + & $*$ & $6 / 6$ & $\mathrm{H} 10$ \\
\hline 13054 & + & + & + & + & + & + & + & + & + & + & + & $*$ & $6 / 6$ & $\mathrm{H} 10$ \\
\hline 0780 & + & + & + & + & + & + & + & + & + & + & + & P12 & $6 / 6$ & H10 \\
\hline 0779 & + & + & + & + & + & + & + & + & + & + & + & P9 & $6 / 6$ & H10 \\
\hline 0748 & + & + & + & + & + & + & + & + & + & + & + & $*$ & $6 / 6$ & H16 \\
\hline 04100 & + & + & + & + & + & + & + & + & + & + & + & $*$ & $6 / 6$ & H16 \\
\hline 04101 & + & + & + & + & + & + & + & + & + & + & + & P15 & $6 / 6$ & H16 \\
\hline 13084 & - & + & - & + & + & + & + & + & + & + & + & $*$ & $6 / 6$ & H17 \\
\hline $10-4 R$ & - & - & - & + & + & + & + & + & + & + & + & P8 & $4 / 6$ & H19 \\
\hline 12084 & - & - & + & + & + & + & + & + & + & + & + & P8 & $4 / 6$ & H19 \\
\hline 09085 & + & + & - & + & + & + & + & + & - & + & - & $\mathrm{P} 2$ & $1 / 6$ & $\mathrm{H} 20$ \\
\hline 0784 & + & + & + & + & + & + & + & + & + & + & + & P1 & $6 / 6$ & $\mathrm{H} 22$ \\
\hline \multicolumn{15}{|l|}{$81 \mathrm{C}$} \\
\hline 09081 & + & + & + & + & + & + & + & + & + & + & + & $\mathrm{P} 2$ & $6 / 6$ & $\mathrm{H} 2$ \\
\hline 0310 & + & + & + & + & + & + & + & + & + & + & + & $*$ & $6 / 6$ & $\mathrm{H} 4$ \\
\hline 0426 & + & + & + & + & + & + & + & + & + & + & + & $*$ & $6 / 6$ & $\mathrm{H} 4$ \\
\hline 0767 & + & + & + & + & + & + & + & + & + & + & + & P13 & $6 / 6$ & $\mathrm{H} 4$ \\
\hline 0580 & + & + & + & + & + & + & + & + & + & + & + & P5 & $6 / 6$ & $\mathrm{H} 4$ \\
\hline 0687 & + & + & + & + & + & + & + & + & + & + & + & P5 & $6 / 6$ & $\mathrm{H} 4$ \\
\hline 0692 & + & + & + & + & + & + & + & + & + & + & + & P5 & $6 / 6$ & $\mathrm{H} 4$ \\
\hline 0691 & + & + & + & + & + & + & + & + & + & + & + & P5 & $6 / 6$ & $\mathrm{H} 4$ \\
\hline 13129 & + & + & + & + & + & + & + & + & + & + & + & $*$ & $6 / 6$ & H9 \\
\hline 0763 & + & + & + & + & + & + & + & + & + & + & + & $\mathrm{P} 4$ & $4 / 6$ & H9 \\
\hline 0775 & + & + & + & + & + & + & + & + & + & + & + & P4 & $6 / 6$ & H9 \\
\hline 08223 & + & + & + & + & + & + & + & + & + & + & + & P3 & $6 / 6$ & H11 \\
\hline 08224 & + & + & + & + & + & + & + & + & + & + & + & P3 & $6 / 6$ & H11 \\
\hline \multicolumn{15}{|l|}{ A } \\
\hline 0312 & + & + & - & + & + & + & + & + & + & + & + & $*$ & $6 / 6$ & $\mathrm{H} 2$ \\
\hline 0315 & + & + & - & + & + & + & + & + & + & + & + & $*$ & $6 / 6$ & $\mathrm{H} 2$ \\
\hline 0314 & + & + & - & + & + & + & + & + & + & + & + & $\mathrm{P} 2$ & $6 / 6$ & $\mathrm{H} 2$ \\
\hline 04108 & + & + & - & + & + & + & + & + & + & + & + & $*$ & $6 / 6$ & $\mathrm{H} 7$ \\
\hline 0459 & + & + & - & + & + & + & + & + & + & + & + & $*$ & $6 / 6$ & $\mathrm{H} 7$ \\
\hline 06124 & + & + & - & + & + & + & + & + & + & + & + & $\mathrm{P} 2$ & $4 / 6$ & $\mathrm{H} 7$ \\
\hline 12083 & + & + & - & + & + & + & + & + & + & + & + & $\mathrm{P} 4$ & $6 / 6$ & $\mathrm{H} 7$ \\
\hline 13048 & + & + & + & + & + & + & + & + & + & + & + & P5 & $4 / 6$ & H8 \\
\hline 13117 & + & + & + & + & + & + & + & + & + & + & + & $\mathrm{P} 2$ & $6 / 6$ & H12 \\
\hline 0317 & + & - & - & + & + & + & + & + & + & + & + & P14 & $6 / 6$ & H18 \\
\hline B & & & & & & & & & & & & & & \\
\hline 0581 & + & + & + & + & + & + & + & + & + & + & + & P5 & $6 / 6$ & $\mathrm{H} 4$ \\
\hline $\mathrm{D}$ & & & & & & & & & & & & & & \\
\hline 04106 & + & + & + & + & + & + & + & + & + & + & + & P7 & $6 / 6$ & H3 \\
\hline 13134 & + & + & + & + & + & + & + & + & + & + & + & P10 & $6 / 6$ & H6 \\
\hline 13090 & + & + & + & + & + & + & + & + & + & + & + & P6 & $6 / 6$ & H6 \\
\hline
\end{tabular}

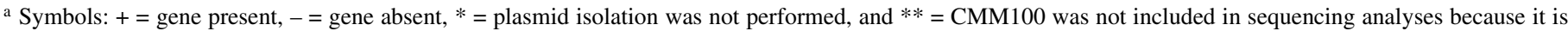
identical to Clavibacter michiganensis subsp. michiganensis strain NCPPB382, minus the two plasmids. Gene location based upon the reference Clavibacter michiganensis subsp. michiganensis strain NCPPB382.

b BOX-A1R pattern and isolate.

c PAI = pathogenicity island.

d Unique plasmid profile patterns for Clavibacter michiganensis subsp. michiganensis isolates determined with pulsed-field gel electrophoresis.

e Disease incidence (DI) expressed as the number of wilting plants per number of inoculated plants 28 days postinoculation.

${ }^{\mathrm{f}} \mathrm{Hap}=$ haplotype: based on the concatenated housekeeping and putative pathogenicity genes. 
$3)$. The most numerous haplotype $(\mathrm{H})$ was $\mathrm{H} 4(n=8)$; followed by $\mathrm{H} 2$ and $\mathrm{H} 16$ (both $n=5$ ); H7 and H10 (both $n=4$ ); H6, H9, and $\mathrm{H} 15$ (all $n=3$ ); H5, H11, and $\mathrm{H} 19$ (all $n=2$ ), and 10 unique haplotypes that were represented only once. Our MLSA scheme provided higher resolution than the BOX-A1R patterns because type A could be further subdivided into five haplotypes, $13 \mathrm{C}$ into five haplotypes, $65 \mathrm{C}$ into nine haplotypes, $81 \mathrm{C}$ into four haplotypes, and D into two haplotypes (Table 3 ). The isolate with the $\mathrm{B}$ BOX-A1R pattern (0581) was a member of the H4 haplotype, which included eight isolates. BOX-A1R patterns tended to cluster together within the ML phylogenetic trees; however, there was not an absolute association between BOX-A1R patterns and haplotypes (Figs. 3 and 4). Different clustering patterns within the phylogenetic trees were observed when only the housekeeping genes were concatenated (Fig. 3) versus the concatenating of both housekeeping genes and putative pathogenicity genes (Fig. 4).

All eight loci used in our MLSA scheme were polymorphic, with $s d h A$ having the most polymorphic sites at 32 and nagA

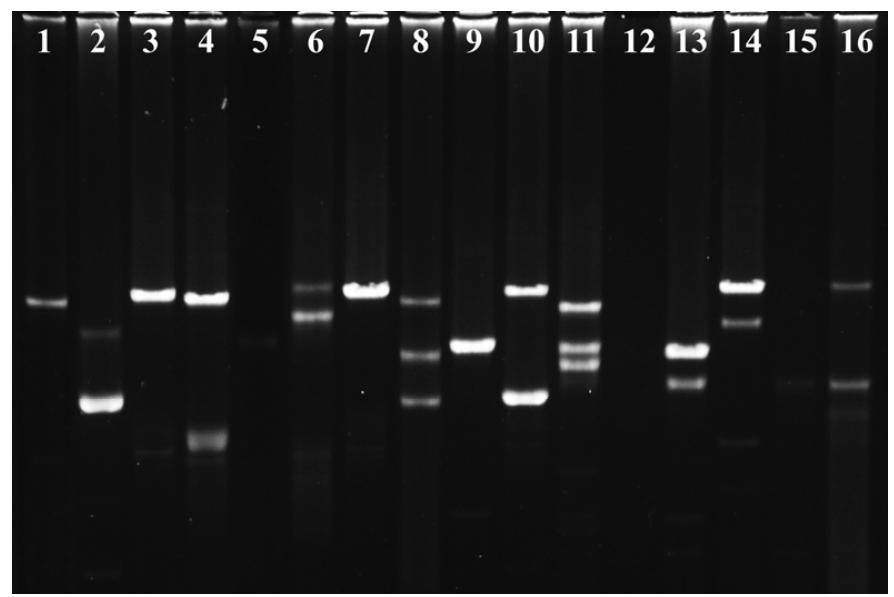

Fig. 2. Pulsed-field gel electrophoresis plasmid profiles representing the most diverse plasmid patterns observed in the New York Clavibacter michiganensis subsp. michiganensis population. Lane $1=\mathrm{P} 14$ (0317), lane $2=\mathrm{P} 16$ (0651), lane $3=\mathrm{P} 2$ (06124), lane $4=\mathrm{P} 1$ (NCPPB382), lane $5=\mathrm{P} 15$ (0676), lane $6=$ P3 (08224), lane $7=$ P4 (12083), lane $8=$ P10 (13134), lane $9=$ P6 (12069), lane $10=$ P5 (13048), lane $11=\mathrm{P} 7(04106)$, lane $12=\mathrm{P} 8(\mathrm{CMM} 100)$, lane 13 = P9 (0779), lane $14=\mathrm{P} 11$ (0572), lane $15=\mathrm{P} 12$ (0780), lane $16=\mathrm{P} 13$ (0767). having the least at 2 polymorphic sites (Table 4). Housekeeping genes $k d p A$ and $s d h A$ showed the greatest amount of variation, with 3.73 and $4.27 \%$ of sites, respectively, being polymorphic in each gene, (Table 4). The three remaining housekeeping genes$d n a A$, $\operatorname{lig} A$, and $\operatorname{gyr} B$ - all had less than $1.0 \%$ of sequence variation. Concatenation of $k d p A$ and $s d h A$ alone produced the same number of haplotypes as concatenating all of the housekeeping genes in isolates of $C$. michiganensis subsp. michiganensis (Table 4). Putative pathogenicity-related genes showed minimal sequence variation compared with the housekeeping genes of $C$. michiganensis subsp. michiganensis, except for celA and tomA, which had 1.33 and $0.786 \%$ of sites, respectively, being polymorphic in each gene (Table 4).

Polymorphic sites were predominately located within coding sequences but three polymorphic sites (including an indel) were identified in the noncoding sequences of celA (Table 4). An identical 20-bp insertion was located $17 \mathrm{bp}$ upstream of the celA start codon in the six New York C. michiganensis subsp. michiganensis isolates: 04106, 0779, 0780, 0784, 13054, and 13091. All of the isolates except 0779 and 0780 originated in different New York counties located in disparate regions of New York, including western New York, central New York, the capital district, and eastern New York, from 2004 to 2013 (Fig. 1). Only four of the isolates-0779, 0780, 13054, and 13091—would consistently group together in the ML phylogenetic trees, but 04106 and 0784 would not (Figs. 3 and 4). The indel was treated as a single polymorphic site.

All MLSA gene sequences were deposited in GenBank (accession numbers dnaA [KJ723713 to KJ723763], gyrB [KJ723764 to $\mathrm{KJ} 723814$ ], $k d p A$ [KJ723815 to KJ723865], ligA [KJ723866 to KJ723916], sdhA [KJ723917 to KJ723967], tomA [KJ723968 to KJ724018], nagA [KJ724019 to KJ724068], and celA [KJ724069 to KJ724116]).

Comparing the genetic diversity of $C$. michiganensis subsp. michiganensis isolates from New York and Serbia. In all, 23 concatenated sequences-ligA, $k d p A, s d h A$, and tomA-were aligned, including 7 Serbian and 16 New York $C$. michiganensis subsp. michiganensis isolates, each representing a unique haplotype (Table 5). Compared with the reference strain NCPPB382, Serbian isolate P520 had the most polymorphic sites, with 44 differences, and Serbian isolate P137 had the fewest polymorphic sites, with only 11 (Table 5). An AMOVA demonstrated that the two populations were not significantly different $(P=0.276)$, with

TABLE 4. Sequence variation in Clavibacter michiganensis subsp. michiganensis isolates

\begin{tabular}{|c|c|c|c|c|c|c|c|}
\hline Gene & $\begin{array}{c}\text { Sequenced } \\
\text { fragment (bp) }\end{array}$ & $\begin{array}{c}\text { Number of isolates } \\
\text { sequenced }^{\mathrm{a}}\end{array}$ & $\begin{array}{l}\text { Number of } \\
\text { haplotypes }\end{array}$ & Indel $^{\text {b }}$ & $\begin{array}{c}\text { Number of } \\
\text { polymorphic sites }(\%)\end{array}$ & $\begin{array}{l}\text { Number of } \\
\text { polymorphic sites in } \\
\text { noncoding sequences }\end{array}$ & $\begin{array}{c}\text { Discriminatory } \\
\text { power }\end{array}$ \\
\hline \multicolumn{8}{|l|}{ Housekeeping } \\
\hline$K d p A$ & 670 & 52 & 12 & 0 & $25(3.73)$ & 0 & 0.868 \\
\hline$S d h A$ & 749 & 52 & 13 & 0 & $32(4.27)$ & 0 & 0.878 \\
\hline DnaA & 833 & 52 & 4 & 0 & $8(0.960)$ & 0 & 0.597 \\
\hline $\operatorname{Lig} A$ & 524 & 52 & 5 & 0 & $4(0.763)$ & 0 & 0.283 \\
\hline$G y r B$ & 501 & 52 & 4 & 0 & $3(0.599)$ & 0 & 0.489 \\
\hline Conc.KdpA-SdhA & 1,419 & 52 & 17 & $\ldots$ & $57(4.02)$ & $\ldots$ & 0.934 \\
\hline Conc.KdpA-GyrB & 3,277 & 52 & 17 & $\ldots$ & $72(2.20)$ & $\ldots$ & 0.934 \\
\hline \multicolumn{8}{|l|}{ Pathogenicity } \\
\hline CelA & 1,126 & 52 & 8 & 1 & $15(1.33)$ & 3 & 0.806 \\
\hline TomA & 509 & 52 & 5 & 0 & $4(0.786)$ & 0 & 0.630 \\
\hline $\operatorname{Nag} A$ & 769 & 52 & 3 & 0 & $2(0.260)$ & 0 & 0.185 \\
\hline ChpE & 674 & 13 & 1 & 0 & 0 & 0 & 0 \\
\hline Pat-1 & 791 & 15 & 1 & 0 & 0 & 0 & 0 \\
\hline PhpA & 688 & 4 & 1 & 0 & 0 & 0 & 0 \\
\hline \multicolumn{8}{|l|}{ Conc. } \\
\hline CelA-NagA & 2,404 & 52 & 18 & $\ldots$ & $21(0.874)$ & $\ldots$ & 0.905 \\
\hline Conc. KdpA-GyrB + CelA-NagA & 5,681 & 52 & 22 & $\ldots$ & $93(1.64)$ & $\ldots$ & 0.946 \\
\hline
\end{tabular}

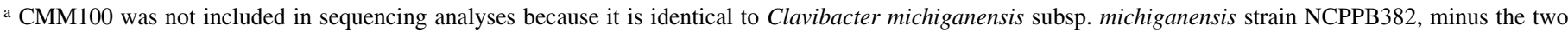
plasmids.

b Number of unique indels detected within sequenced fragment. Each indel was treated as a single polymorphic site. 
$98 \%$ of the genetic variation occurring within populations and only $2 \%$ of the genetic variation occurring between populations. Both Serbian and New York isolates were distributed throughout an ML phylogenetic tree with no distinct population clusters (Fig. 5). Several New York and Serbian isolates demonstrated high levels of similarity, most notably 0317 and P121.

\section{DISCUSSION}

New York C. michiganensis subsp. michiganensis isolates collected from diseased plants over an 11-year period were highly diverse. The majority of isolates were pathogenic but differences in disease incidence were observed. However, the association of virulence with putative pathogenicity genes or plasmids was not always absolute. Several isolates with plasmids and all six putative pathogenicity genes produced symptoms identical to isolates lacking some pathogenicity genes and plasmids. Similarly, plasmid profiles were unique, diverse, and different from both Serbian and Israeli $C$. michiganensis subsp. michiganensis populations $(18,28)$.

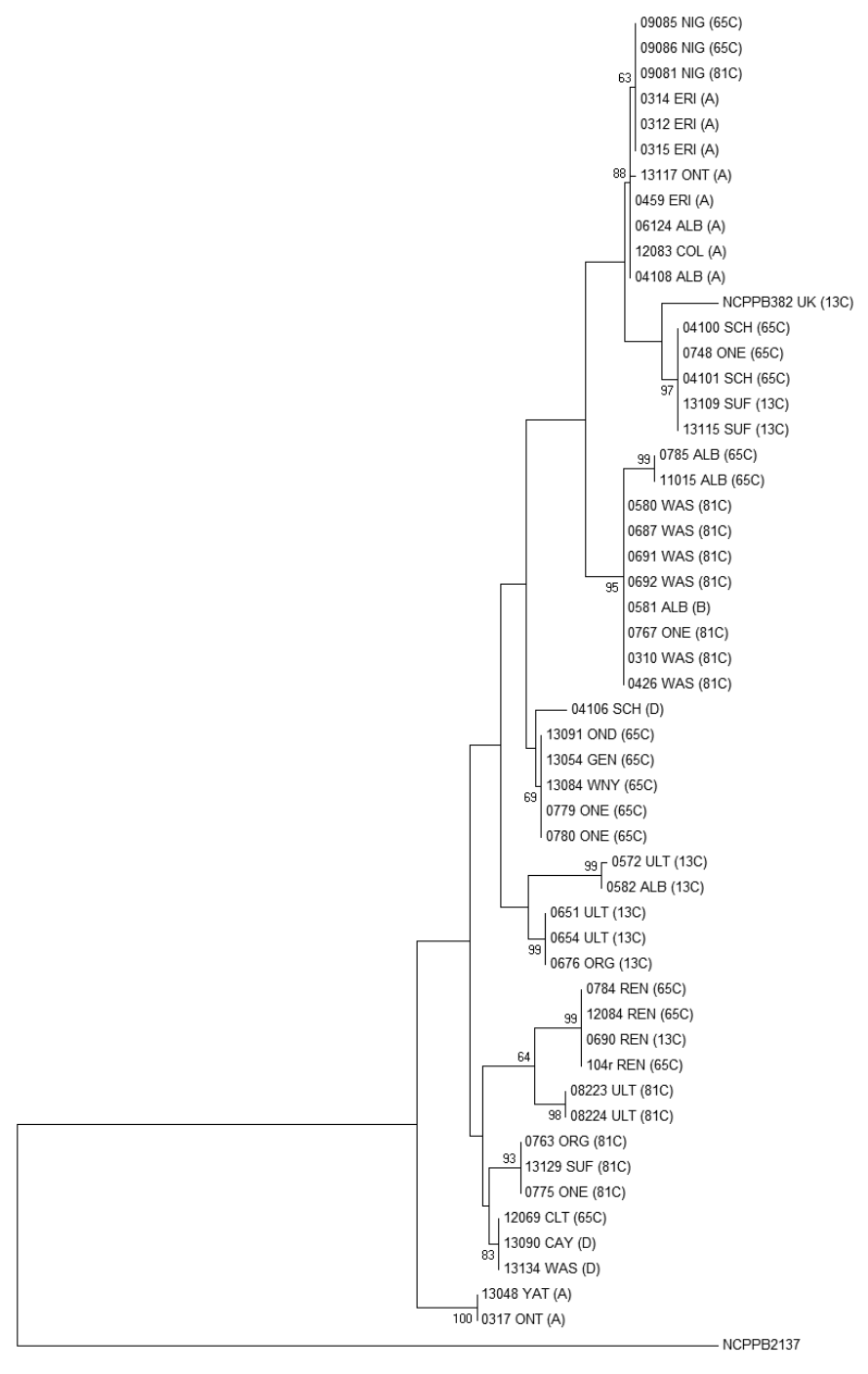

Fig. 3. Maximum-likelihood phylogenetic tree for the concatenated housekeeping genes-dnaA, gyrB, $\operatorname{lig} A, k d p A$, and $s d h A$-for New York Clavibacter michiganensis subsp. michiganensis isolates $(n=51)$, reference $C$. michiganensis subsp. michiganensis strain NCPPB382, and reference C. michiganensis subsp. sepedonicus strain NCPPB2137. Isolate numbers, county symbols, and BOX-A1R patterns are indicated. Bootstrap values are shown at the nodes if greater than $50 \%$. The tree is drawn to scale, with branch lengths measured in the number of substitutions per site (42).
All six BOX-A1R patterns were present in New York, with the $\mathrm{C}$ (13C, 65C, and 81C) and A types being the most prevalent, while B and D were rare. Similar observations were observed in Michigan, where the most prevalent BOX-A1R pattern was $\mathrm{C}$, with $\mathrm{A}, \mathrm{B}$, and $\mathrm{D}$ being observed in a limited number of regions (33). In contrast, Japanese and Israeli $C$. michiganensis subsp. michiganensis populations were predominately $\mathrm{B}$ and $\mathrm{A}$, with types $\mathrm{C}$ and $\mathrm{D}$ being less abundant in Japan and rare in Israel $(17,18)$. Unfortunately, the benefits of utilizing rep-PCR as a method of determining population structure, whether within fields or regions, is limited because of its low discriminatory power, subjectiveness, and low interlab reproducibility. Therefore, we used an MLSA scheme with a high discriminatory power (0.946), which allowed for a more detailed interpretation of the diversity and potential movement of C. michiganensis subsp. michiganensis isolates.

The MLSA assay revealed that putative pathogenicity genes were much more conserved than housekeeping genes in New York isolates, with chpE, pat-1, and phpA having no polymorphic sites in the sequenced regions, while nagA only had two singlenucleotide polymorphisms (SNPs). Similar results were observed with the Serbian $C$. michiganensis subsp. michiganensis isolates, where no SNPs were present within the related serine protease gene $\operatorname{chpC}$ (28). Conversely, a 2012 Michigan C. michiganensis subsp. michiganensis survey found pat-1 to be the most variable gene, with 45 SNPs identified in the 96 isolates sampled, even though the same region was sequenced in the present study (33). Unfortunately, pat-1 and celA were the only shared genes between the current study and the Michigan survey; therefore, population diversity comparisons could not be made (33).

Only one isolate in this study, 09085, lacked $\operatorname{chpE}$ or nagA and was also greatly reduced in virulence. Although we obviously cannot conclude that the losses of these two genes are responsible for reduction in virulence, the potential role of the gene products

TABLE 5. Sequence variation in concatenated genes (ligA, $k d p A$, $s d h A$, and tomA) for Clavibacter michiganensis subsp. michiganensis isolates from New York and Serbia, in respect to reference strain NCPPB382

\begin{tabular}{lcc}
\hline Origin, isolate $^{\mathrm{a}}$ & Sites $^{\mathrm{b}}$ & SNPs $^{\mathrm{c}}$ \\
\hline New York & & \\
0314 & 20 & $26.6( \pm 8.5)$ \\
06124 & 19 & $\ldots$ \\
13117 & 20 & $\ldots$ \\
11015 & 30 & $\ldots$ \\
0767 & 27 & $\ldots$ \\
0572 & 20 & $\ldots$ \\
0582 & 19 & $\ldots$ \\
04101 & 13 & $\ldots$ \\
04106 & 24 & $\ldots$ \\
0651 & 21 & $\ldots$ \\
0779 & 27 & $\ldots$ \\
13129 & 35 & $\ldots$ \\
12069 & 32 & $\ldots$ \\
0317 & 36 & $\ldots$ \\
08223 & 42 & $\ldots$ \\
0690 & 40 & $\ldots$ \\
Serbia & & $\ldots$ \\
P10 & 27 & $\ldots$ \\
P64 & 24 & $\ldots$ \\
P70 & 27 & $\ldots$ \\
P121 & 40 & $\ldots$ \\
P137 & 11 & $\ldots$ \\
P520 & 27 & $\ldots$ \\
\hline
\end{tabular}

a Selected isolates represent unique haplotypes observed in either New York or Serbia. Unique New York haplotypes from the concatenated housekeeping genes $(n=16)$ and unique Serbian isolates from each of the seven multilocus sequence typing groups $(n=7)$ were selected (28).

${ }^{b}$ Number of polymorphic sites was determined by comparing sequences to the reference Clavibacter michiganensis subsp. michiganensis strain NCPPB382.

${ }^{c}$ Average number of single-nucleotide proteins (SNPs) ( \pm standard deviation). 
in pathogenicity is interesting. Both $\mathrm{ChpE}$ and NagA are produced in planta, contain signal peptides, and are upregulated $>18$ or $>20$-fold, respectively, during infection-mimicking conditions (36). The role of nagA is unknown but $\beta$ - $\mathrm{N}$-acetylglucosaminidase (or the $\mathrm{N}$-acetylglucosamine metabolic family) has been associated with virulence in a variety of bacterial and eukaryotic pathogens, including Xanthomonas campestris pv. campestris, Candida albicans, Streptococcus pneumonia, and Vibrio cholerae $(3,6,15,21,32)$. Within $V$. cholerae, genes involved in the utilization of $\mathrm{N}$-acetylglucosamine (nan-nag region) were found to reside in the VPI-2 pathogenicity island, similarly to nagA residing within the pathogenicity island of $C$. michiganensis subsp. michiganensis (15). The functions of these $\mathrm{N}$-acetylglucosamine catabolic genes, especially $\beta$-N-acetylglucosaminidase, remain speculative; however, in S. pneumonia, they are hypothesized to provide an adhesive function in biofilm formations (3).

The $\operatorname{chpE}$ gene is interesting because it was found to be the most highly upregulated putative serine protease within the $\operatorname{chp}$ gene cassette-chpA-chpG-under infection-mimicking conditions (36). Three of the $\operatorname{chp}$ genes- $\operatorname{ch} p A, \operatorname{ch} p B$, and $\operatorname{chpD}$-are pseudogenes and, although the function of the remaining four
Chp peptides is unknown, they are hypothesized to facilitate plant colonization and nutrient acquisition (40).

Out of the three plasmid-associated pathogenicity-related genes ( $p h p A$, celA, and pat-1), 14 isolates lacked at least one of the three, with $p h p A$ being the most common gene to be lost $(n=13)$ and celA the least likely to be lost $(n=3)$. A large proportion of the isolates that lost the $p h p A$ gene were clustered in the A BOXA1R PCR pattern $(n=8)$, yet no correlation with virulence and loss of phpA was observed (Table 3). Interestingly, C. michiganensis subsp. michiganensis 0317 lacked both celA and phpA but was pathogenic on tomato (disease incidence of 6/6), while the two remaining isolates that lacked celA (12084 and 10-4R) had a disease incidence of only 4/6. This further demonstrates the variability in virulence observed among a diverse population of field isolates and the hypothesized importance of putative pathogenicity genes. Similar observations were reported in a study by Yasuhara-Bell et al. (47), who found that field isolates remained pathogenic even though the putative pathogenicity genes $\operatorname{chpC}$ or ppaA were absent.

Six New York C. michiganensis subsp. michiganensis isolates possessed a 20-bp insertion upstream of the celA start codon but no clear association with disease incidence was observed during

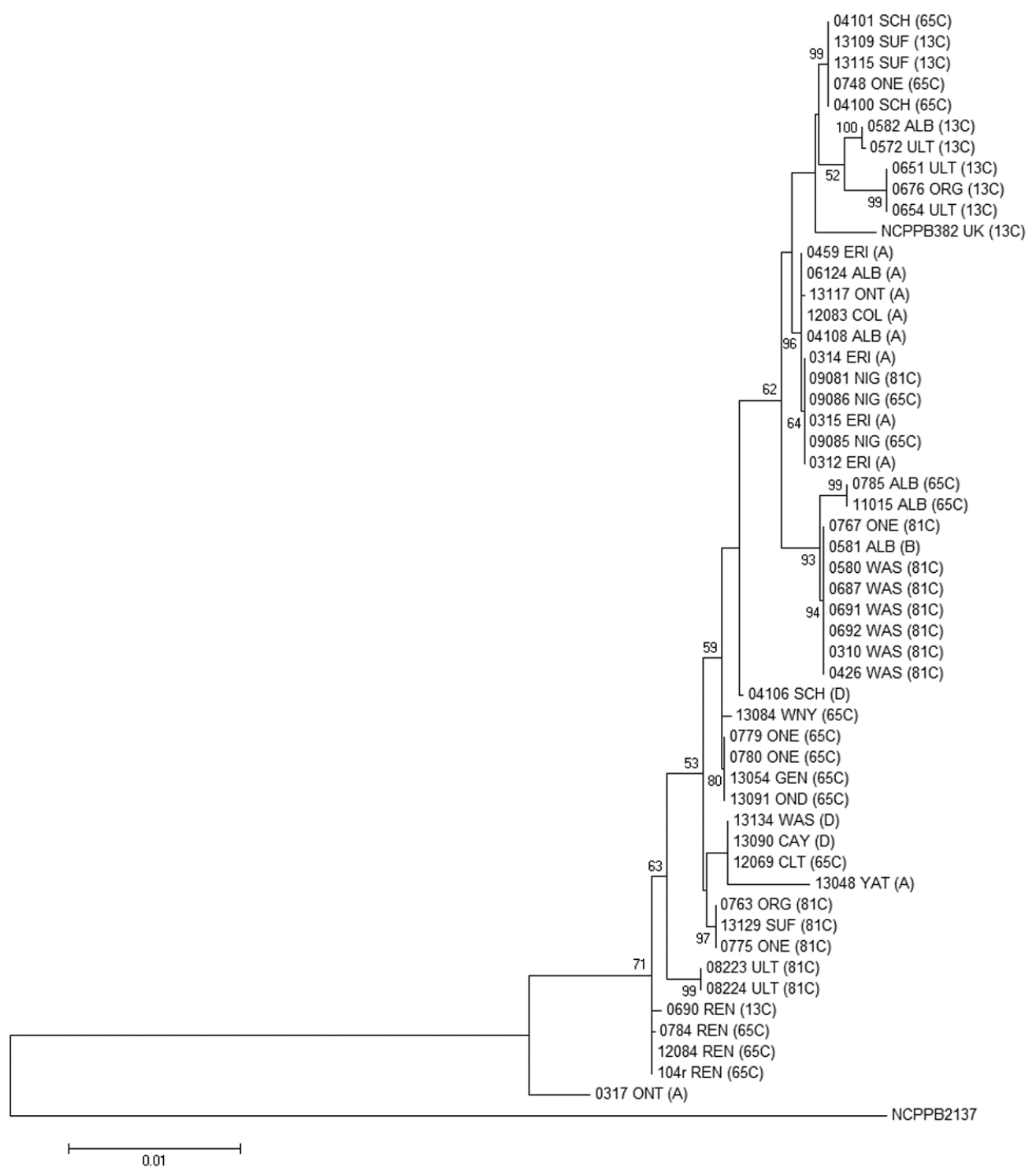

Fig. 4. Maximum-likelihood phylogenetic tree for the concatenated housekeeping and putative pathogenicity genes—dnaA, gyrB, $\operatorname{lig} A, \operatorname{kdp} A, \operatorname{sh} A, \operatorname{tom} A, \operatorname{nag} A$, and celA—for New York Clavibacter michiganensis subsp. michiganensis isolates $(n=51)$, reference C. michiganensis subsp. michiganensis strain NCPPB382, and reference C. michiganensis subsp. sepedonicus strain NCPPB2137. Isolate numbers, county symbols, and BOX-A1R patterns are indicated. Bootstrap values are shown at the nodes if greater than 50\%. The tree is drawn to scale, with branch lengths measured in the number of substitutions per site (42). 
the greenhouse pathogenicity assays. The presence of this insertion in only six isolates observed over a 10-year period (2004 to 2013) in disparate regions of New York is intriguing but highlights the dynamic nature of pathogenicity genes within populations of $C$. michiganensis subsp. michiganensis. Pathogenicity genes within conjugative plasmids, such as is the case with pCM1 and pCM2 in NCPPB382, could be rapidly dispersed throughout a population and transfer novel genetic variations that could be advantageous under specific environmental conditions (8).

The ephemeral nature of virulence within field populations of C. michiganensis subsp. michiganensis can be difficult to study because the isolation of avirulent isolates from diseased plants is relatively rare (12). In our study, however, several isolates (isolated from the same farm over a 7-year period) had differences in putative pathogenicity genes but the highly polymorphic housekeeping genes remained conserved. For example, 0690 was isolated from a farm for the first time in Rensselaer County during 2006 and the same haplotype (based on housekeeping genes) was reisolated from the farm during a 2007 outbreak (0784). The grower took appropriate measures and successfully suppressed bacterial canker outbreaks from 2008 to 2011; unfortunately, the same haplotype (based on housekeeping genes) was again reisolated in a 2012 outbreak (12084). Unexpectedly, an irrigation water survey detected viable colonies of the same haplotype (based on housekeeping genes) of C. michiganensis subsp. michiganensis in creek irrigation water from the same county but different cities (approximately 24 miles away) during 2010 $(10-4 \mathrm{R})(16)$. Therefore, it appears that the isolate was maintained in or around the surrounding area for several years without any noticeable (or reported) outbreaks occurring, possibly due to improper sanitation measures.
The initial 2006 (0690) and 2007 (0784) C. michiganensis subsp. michiganensis isolates each possessed the six putative pathogenicity-related genes with the same plasmid profiles; however, five SNPs were detected within the celA gene, including a 20-bp insertion upstream of the promoter in 0784, thereby differentiating 0690 and 0784 . In contrast, 10-4R and 12084 lost their plasmids (profile P8), with 10-4R losing pat-1, celA, and phpA and 12084 only losing pat-1 and celA, based on our PCR analysis. All of the isolates were pathogenic based on greenhouse studies but 10-4R and 12084 were weak pathogens.

The reemergence of an identical haplotype over an extended period of time highlights the difficulty in properly managing bacterial canker outbreaks. This trend has been observed several times, including isolates 0785 and 11015 (identical haplotype and collected from the same farm 4 years later); isolates 0317 and 13048 (identical haplotype based on housekeeping genes but isolated from farms in adjoining counties 11 years apart); and isolates 0310, 0426, 0580, 0687, 0691, and 0692 (identical haplotype collected from the same grower over a 4-year period). Alternatively, novel haplotypes (0310, 0317, 04016, 0582, 0690, $0785,08223,13084$, and 13117) that were isolated from farms with no previous history of $C$. michiganensis subsp. michiganensis, could have been introduced from infected seed or transplants. Having the ability to utilize MLSA to identify strains (both novel and old) could assist growers by demonstrating that they could be maintaining the same population of $C$. michiganensis subsp. michiganensis on their farms due to improper sanitation methods or from an introduction event.

In addition to looking at the genetic diversity at a statewide level, we wanted to better understand global $C$. michiganensis subsp. michiganensis populations, and a recent study from Serbia

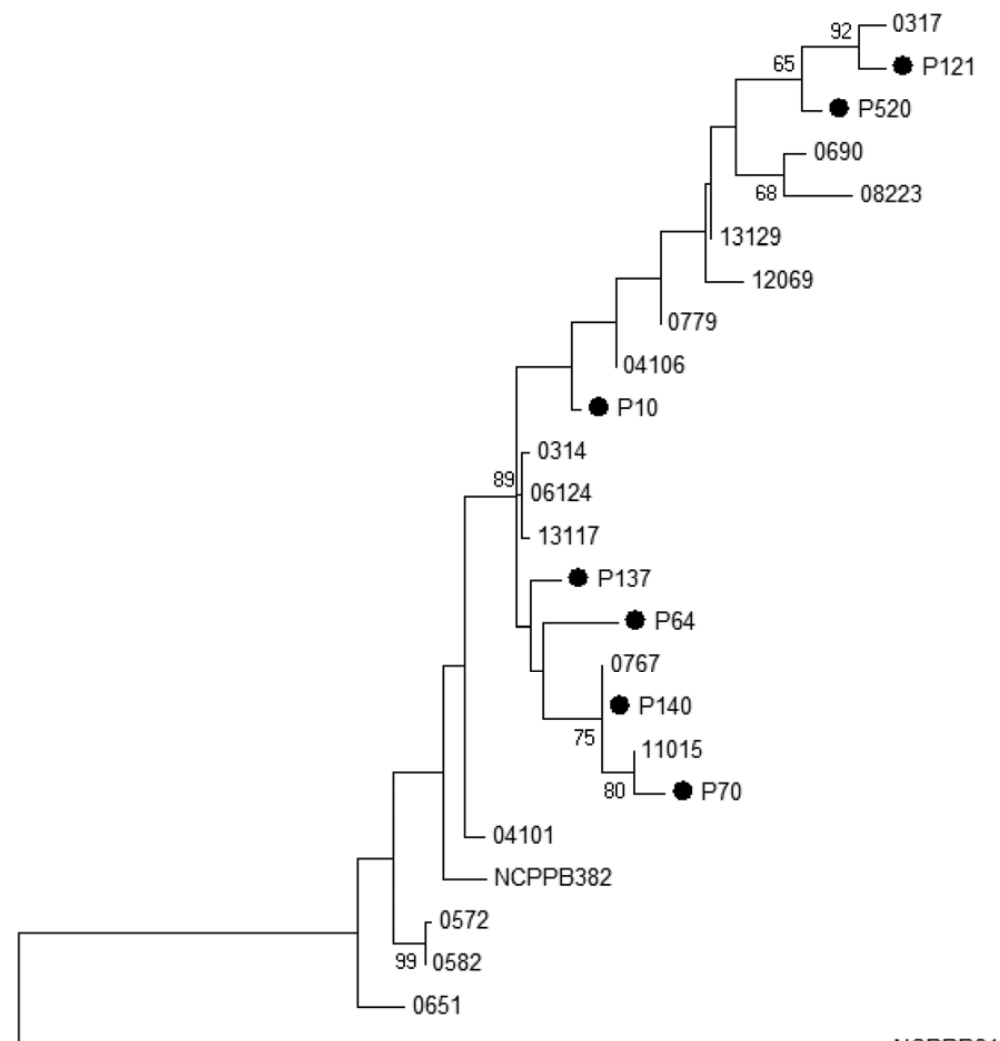

NCPPB2137

0.01

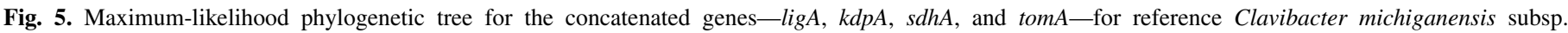

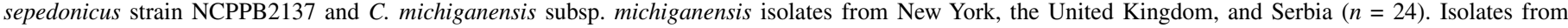

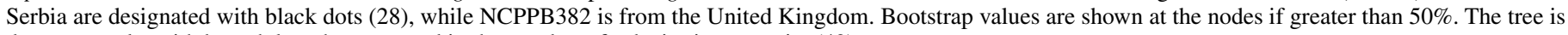
drawn to scale, with branch lengths measured in the number of substitutions per site (42). 
enabled such a comparison due to the overlap in primer sets (28). Interestingly, $98 \%$ of the genetic variation observed between New York and Serbian isolates occurred within populations and only $2 \%$ of the genetic variation occurred between populations. This low level of genetic variation between two geographically separated populations could suggest that both populations shared a common origin. Additionally, the lack of any significant divergence occurring between the two populations could further demonstrate a recent introduction event. Accordingly, MilijaševićMarčić et al. (28) noted that bacterial canker outbreaks have gone unreported for approximately 50 years in Serbia, until large greenhouse outbreaks occurred around 2006 to 2008 throughout the country. Further insight into the movement and population biology of $C$. michiganensis subsp. michiganensis could be formulated, with additional populations being examined and compared.

The data presented here demonstrate that the New York population of $C$. michiganensis subsp. michiganensis is highly diverse, with 21 haplotypes observed over an 11-year period. Several of the isolates are reoccurring but many are novel and have been observed on farms with no previous history of bacterial canker of tomato. Our MLSA scheme, comprising five housekeeping genes and three putative pathogenicity genes, resulted in a discriminatory power of 0.946 . Interestingly, a recent phylogenetic analysis (MLSA) of C. michiganensis had a discriminatory power of 0.972 (with 48 haplotypes) for six housekeeping genes (14). That analysis included all five $C$. michiganensis subspecies (plus unknown Clavibacter-like saprophytes) with 69 globally collected C. michiganensis subsp. michiganensis isolates from over a halfcentury of collections (14). It was interesting to observe a similar amount of diversity when just New York $C$. michiganensis subsp. michiganensis isolates from an 11-year period were analyzed. Moreover, a multilocus variable-number tandem-repeats analysis from 56 European C. michiganensis subsp. michiganensis isolates collected from over a half-century resulted in a discriminatory power of just 0.800 (48).

Overall, it becomes ever more important for the consistent use of the most polymorphic genes (as a common standard) to be set for future $C$. michiganensis subsp. michiganensis population studies. Hopefully, additional researchers will characterize their C. michiganensis subsp. michiganensis populations using an MLSA approach, in which comprehensive epidemiological patterns may be observed that will better illuminate the population biology of this devastating plant pathogen.

\section{ACKNOWLEDGMENTS}

This research was supported by grant number IS-4403-11C from the United States-Israel Binational Agricultural Research and Development (BARD) Fund. Support for M. Tancos was additionally provided by a fellowship from Cornell University College of Agriculture and Life Sciences and the National Science Foundation-Graduate Research Fellowships Program (GRFP) grant number DGE-1144153. We thank $\mathrm{K}$. Bekoscke and members of the Smart lab for assisting with various experiments.

\section{LITERATURE CITED}

1. Balaji, V., Mayrose, M., Sherf, O., Jacob-Hirsch, J., Eichenlaub, R., Iraki, N., Manulis-Sasson, S., Rechavi, G., Barash, I., and Sessa, G. 2008. Tomato transcriptional changes in response to Clavibacter michiganensis subsp. michiganensis reveal a role for ethylene in disease development. Plant Physiol. 146:1797-1809.

2. Balaji, V., and Smart, C. D. 2012. Over-expression of snakin-2 and extensin-like protein genes restricts pathogen invasiveness and enhances tolerance to Clavibacter michiganensis subsp. michiganensis in transgenic tomato (Solanum lycopersicum). Transgenic Res. 21:23-37.

3. Bateman, A., Holden, M. T. G., and Yeats, C. 2005. The G5 domain: A potential $\mathrm{N}$-acetylglucosamine recognition domain involved in biofilm formation. Bioinformatics 21:1301-1303.
4. Bentley, S. D., Corton, C., Brown, S. E., Barron, A., Clark, L., Doggett, J., Harris, B., Ormond, D., Quail, M. A., May, G., Francis, D., Knudson, D., Parkhill, J., and Ishimaru, C. A. 2008. Genome of the actinomycete plant pathogen Clavibacter michiganensis subsp. sepedonicus suggests recent niche adaptation. J. Bacteriol. 190:2150-2160.

5. Bryan, M. K. 1930. Studies on bacterial canker of tomato. J. Agric. Res. 41:825-851.

6. Cannon, R., Niimi, K., Jenkinson, H., and Shepherd, M. 1994. Molecular cloning and expression of the Candida albicans beta-N-acetylglucosaminidase (HEX1) gene. J. Bacteriol. 176:2640-2647.

7. Carlton, W. M., Braun, E. J., and Gleason, M. L. 1998. Ingress of Clavibacter michiganensis subsp. michiganensis into tomato leaves through hydathodes. Phytopathology 88:525-529.

8. Chalupowicz, L., Cohen-Kandli, M., Dror, O., Eichenlaub, R., Gartemann, K.-H., Sessa, G., Barash, I., and Manulis-Sasson, S. 2010. Sequential expression of bacterial virulence and plant defense genes during infection of tomato with Clavibacter michiganensis subsp. michiganensis. Phytopathology 100:252-261.

9. Chalupowicz, L., Zellermann, E.-M., Fluegel, M., Dror, O., Eichenlaub, R., Gartemann, K.-H., Savidor, A., Sessa, G., Iraki, N., Barash, I., and Manulis-Sasson, S. 2012. Colonization and movement of GFP-labeled Clavibacter michiganensis subsp. michiganensis during tomato infection. Phytopathology 102:23-31.

10. Chen, Y., Zhang, W., and Knabel, S. J. 2007. Multi-virulence-locus sequence typing identifies single nucleotide polymorphisms which differentiate epidemic clones and outbreak strains of Listeria monocytogenes. J. Clin. Microbiol. 45:835-846.

11. Chun, W. 1982. Identification and detection of Corynebacterium michiganense in tomato seed using the indirect enzyme-linked immunosorbent assay. M.Sc. thesis, University of Hawaii.

12. Eichenlaub, R., and Gartemann, K.-H. 2011. The Clavibacter michiganensis subspecies: Molecular investigation of gram-positive bacterial plant pathogens. Annu. Rev. Phytopathol. 49:445-464.

13. Gartemann, K.-H., Abt, B., Bekel, T., Burger, A., Engemann, J., Flügel, M., Gaigalat, L., Goesmann, A., Gräfen, I., Kalinowski, J., Kaup, O., Kirchner, O., Krause, L., Linke, B., McHardy, A., Meyer, F., Pohle, S., Rückert, C., Schneiker, S., Zellermann, E. M., Pühler, A., Eichenlaub, R., Kaiser, O., and Bartels, D. 2008. The genome sequence of the tomatopathogenic actinomycete Clavibacter michiganensis subsp. michiganensis NCPPB382 reveals a large island involved in pathogenicity. J. Bacteriol. 190:2138-2149.

14. Jacques, M.-A., Durand, K., Orgeur, G., Balidas, S., Fricot, C., Bonneau, S., Quillévéré, A., Audusseau, C., Olivier, V., Grimault, V., and Mathis, R. 2012. Phylogenetic analysis and polyphasic characterization of Clavibacter michiganensis strains isolated from tomato seeds reveal that nonpathogenic strains are distinct from $C$. michiganensis subsp. michiganensis. Appl. Environ. Microbiol. 78:8388-8402.

15. Jermyn, W. S., and Boyd, E. F. 2002. Characterization of a novel Vibrio pathogenicity island (VPI-2) encoding neuraminidase (nanH) among toxigenic Vibrio cholerae isolates. Microbiology 148:3681-3693.

16. Jones, L. A. 2014. Prevalence and longitudinal study of human and plant pathogens in New York surface irrigation water, UV surface water treatment, and genome-assisted diagnostic protocol development for virulent field strains of Pseudomonas syringae pv. tomato 1-114. Ph.D. thesis, Cornell University, Geneva, NY.

17. Kawaguchi, A., Tanina, K., and Inoue, K. 2010. Molecular typing and spread of Clavibacter michiganensis subsp. michiganensis in greenhouses in Japan. Plant Pathol. 59:76-83.

18. Kleitman, F., Barash, I., Burger, A., Iraki, N., Falah, Y., Sessa, G., Weinthal, D., Chalupowicz, L., Gartemann, K.-H., Eichenlaub, R., and Manulis-Sasson, S. 2008. Characterization of a Clavibacter michiganensis subsp. michiganensis population in Israel. Eur. J. Plant Pathol. 121:463-475.

19. Koressaar, T., and Remm, M. 2007. Enhancements and modifications of primer design program Primer3. Bioinformatics 23:1289-1291.

20. Köser, C. U., Ellington, M. J., Cartwright, E. J. P., Gillespie, S. H., Brown, N. M., Farrington, M., Holden, M. T. G., Dougan, G., Bentley, S. D., Parkhill, J., and Peacock, S. J. 2012. Routine use of microbial whole genome sequencing in diagnostic and public health microbiology. PLoS Pathog. 8:e1002824.

21. Kumar, M. J., Jamaluddin, M. S., Natarajan, K., Kaur, D., and Datta, A. 2000. The inducible $\mathrm{N}$-acetylglucosamine catabolic pathway gene cluster in Candida albicans: Discrete N-acetylglucosamine-inducible factors interact at the promoter of NAG1. Proc. Natl. Acad. Sci. USA 97:1421814223.

22. De León, L., Rodríguez, A., Llop, P., López, M. M., and Siverio, F. 2009. Comparative study of genetic diversity of Clavibacter michiganensis subsp. michiganensis isolates from the Canary Islands by RAPD-PCR, BOX-PCR and AFLP. Plant Pathol. 58:862-871.

23. De León, L., Siverio, F., López, M. M., and Rodríguez, A. 2011. 
Clavibacter michiganensis subsp. michiganensis, a seedborne tomato pathogen: Healthy seeds are still the goal. Plant Dis. 95:1328-1338.

24. Louws, F. J., Bell, J., Medina-Mora, C. M., Smart, C. D., Opgenorth, D., Ishimaru, C. A., Hausbeck, M. K., de Bruijn, F. J., and Fulbright, D. W. 1998. rep-PCR-mediated genomic fingerprinting: A rapid and effective method to identify Clavibacter michiganensis. Phytopathology 88:862868 .

25. Louws, F. J., Fulbright, D., Stephens, C., and de Bruijn, F. J. 1994. Specific genomic fingerprints of phytopathogenic Xanthomonas and Pseudomonas pathovars and strains generated with repetitive sequences and PCR. Appl. Environ. Microbiol. 60:2286-2295.

26. Meletzus, D., Bermphol, A., Dreier, J., and Eichenlaub, R. 1993. Evidence for plasmid-encoded virulence factors in the phytopathogenic bacterium Clavibacter michiganensis subsp. michiganensis NCPPB382. J. Bacteriol. 175:2131-2136.

27. Meletzus, D., and Eichenlaub, R. 1991. Transformation of the phytopathogenic bacterium Clavibacter michiganense subsp. michiganense by electroporation and development of a cloning vector. J. Bacteriol. 173:184-190.

28. Milijašević-Marčić, S., Gartemann, K., Frohwitter, J., Eichenlaub, R., Todorovic, B., Rekanovic, E., and Potocnik, I. 2012. Characterization of Clavibacter michiganensis subsp. michiganensis strains from recent outbreaks of bacterial wilt and canker in Serbia. Eur. J. Plant Pathol. 134:697-711.

29. Nazari, F., Niknam, G. R., Ghasemi, A., Taghavi, S. M., Momeni, H., and Torabi, S. 2007. An investigation on strains of Clavibacter michiganensis subsp. michiganensis in north and north west of Iran. J. Phytopathol. 155:563-569.

30. Peakall, R., and Smouse, P. E. 2006. GENALEX 6: Genetic analysis in Excel. Population genetic software for teaching and research. Mol. Ecol. Notes 6:288-295.

31. Peakall, R., and Smouse, P. E. 2012. GenAlEx 6.5: Genetic analysis in Excel. Population genetic software for teaching and research-an update. Bioinformatics 28:2537-2539.

32. Qian, W., Jia, Y., Ren, S.-X., He, Y.-Q., Feng, J.-X., Lu, L.-F., Sun, Q., Ying, G., Tang, D.-J., Tang, H., Wu, W., Hao, P., Wang, L., Jiang, B.-L., Zeng, S., Gu, W.-Y., Lu, G., Rong, L., Tian, Y., Yao, Z., Fu, G., Chen, B., Fang, R., Qiang, B., Chen, Z., Zhao, G.-P., Tang, J. L., and He, C. 2005. Comparative and functional genomic analyses of the pathogenicity of phytopathogen Xanthomonas campestris pv. campestris. Genome Res. 15:757-767.

33. Quesada-Ocampo, L., Landers, N., Lebeis, A., Fulbright, D., and Hausbeck, M. 2012. Genetic structure of Clavibacter michiganensis subsp. michiganensis populations in Michigan commercial tomato fields. Plant Dis. 96:788-796.

34. Reid, S. D., Green, N. M., Buss, J. K., Lei, B., and Musser, J. M. 2001. Multilocus analysis of extracellular putative virulence proteins made by group A Streptococcus: Population genetics, human serologic response, and gene transcription. Proc. Natl. Acad. Sci. USA 98:7552-7557.

35. Richert, K., Brambilla, E., and Stackebrandt, E. 2005. Development of PCR primers specific for the amplification and direct sequencing of $g y r B$ genes from microbacteria, order Actinomycetales. J. Microbiol. Methods 6:115-123.

36. Savidor, A., Teper, D., Gartemann, K.-H., Eichenlaub, R., Chalupowicz,
L., Manulis-Sasson, S., Barash, I., Tews, H., Mayer, K., Giannone, R. J. Hettich, R. L., and Sessa, G. 2012. The Clavibacter michiganensis subsp. michiganensis-tomato interactome reveals the perception of pathogen by the host and suggests mechanisms of infection. J. Proteome Res. 11:736750 .

37. Schneider, K. L., Marrero, G., Alvarez, A. M., and Presting, G. G. 2011. Classification of plant associated bacteria using RIF, a computationally derived DNA marker. PLoS One 6:e18496.

38. Sen, Y., Feng, Z., Vandenbroucke, H., van der Wolf, J., Visser, R. G. F., and van Heusden, A. W. 2013. Screening for new sources of resistance to Clavibacter michiganensis subsp. michiganensis $(\mathrm{Cmm})$ in tomato. Euphytica 190:309-317.

39. Shariat, N., Sandt, C. H., DiMarzio, M. J., Barrangou, R., and Dudley, E. G. 2013. CRISPR-MVLST subtyping of Salmonella enterica subsp. enterica serovars Typhimurium and Heidelberg and application in identifying outbreak isolates. BMC Microbiol. 13:254-271.

40. Stork, I., Gartemann, K., Burger, A., and Eichenlaub, R. 2008. A family of serine proteases of Clavibacter michiganensis subsp. michiganensis: chpC plays a role in colonization of the host plant tomato. Mol. Plant Pathol. 9:599-608.

41. Tamura, K., and Nei, M. 1993. Estimation of the number of nucleotide substitutions in the control region of mitochondrial DNA in humans and chimpanzees. Mol. Biol. Evol. 10:512-526.

42. Tamura, K., Peterson, D., Peterson, N., Stecher, G., Nei, M., and Kumar, S. 2011. MEGA 5: Molecular evolutionary genetics analysis using maximum likelihood, evolutionary distance, and maximum parsimony methods. Mol. Biol. Evol. 28:2731-2739.

43. Tancos, M. A., Chalupowicz, L., Barash, I., Manulis-Sasson, S., and Smart, C. D. 2013. Tomato fruit and seed colonization by Clavibacter michiganensis subsp. michiganensis through external and internal routes. Appl. Environ. Microbiol. 79:6948-6957.

44. Untergrasser, A., Cutcutache, I., Koressaar, T., Ye, J., Faircloth, B., Remm, M., and Rozen, S. 2012. Primer3-New capabilities and interfaces. Nucleic Acids Res. 40:e115.

45. Werner, N., Fulbright, D., Podolsky, R., Bell, J., and Hausbeck, M. K. 2002. Limiting populations and spread of Clavibacter michiganensis subsp. michiganensis on seedling tomatoes in the greenhouse. Plant Dis. $86: 535-542$

46. Wicker, E., Lefeuvre, P., de Cambiaire, J.-C., Lemaire, C., Poussier, S., and Prior, P. 2012. Contrasting recombination patterns and demographic histories of the plant pathogen Ralstonia solanacearum inferred from MLSA. ISME J. 6:961-974.

47. Yasuhara-Bell, J., Kubota, R., Jenkins, D. M., and Alvarez, A. M. 2013. Loop-mediated amplification of the Clavibacter michiganensis subsp. michiganensis micA gene is highly specific. Phytopathology 103:1220-1226.

48. Zaluga, J., Stragier, P., Van Vaerenbergh, J., Maes, M., De Vos, P., Vaerenbergh, J. Van, and Vos, P. De. 2013. Multilocus variable-numbertandem-repeats analysis (MLVA) distinguishes a clonal complex of Clavibacter michiganensis subsp. michiganensis strains isolated from recent outbreaks of bacterial wilt and canker in Belgium. BMC Microbiol. 13:126-141.

49. Zhang, W., Jayarao, B., and Knabel, S. 2004. Multi-virulence-locus sequence typing of Listeria monocytogenes. Appl. Environ. Microbiol. 70:913-920. 